\title{
Research on the Impact of Stock Information Content on Enterprise Innovation
}

\author{
Hao Wang ${ }^{1}$, Xinyan $\mathrm{Li}^{2}$, Wenjing Hao ${ }^{3}$ \\ ${ }^{1}$ School of Finance, Anhui University of Finance and Economics, Bengbu, China \\ ${ }^{2}$ School of International Economics and Trade, Anhui University of Finance and Economics, Bengbu, China \\ ${ }^{3}$ School of Business Administration, Anhui University of Finance and Economics, Bengbu, China \\ Email:wanghao000506@163.com
}

How to cite this paper: Wang, H., Li, X. Y., \& Hao, W. J. (2020). Research on the Impact of Stock Information Content on Enterprise Innovation. Open Journal of Social Sciences, 8, 174-189.

https://doi.org/10.4236/jss.2020.811017

Received: October 27, 2020

Accepted: November 17, 2020

Published: November 20, 2020

Copyright (c) 2020 by author(s) and Scientific Research Publishing Inc. This work is licensed under the Creative Commons Attribution International License (CC BY 4.0).

http://creativecommons.org/licenses/by/4.0/

\section{(cc) (i) Open Access}

\begin{abstract}
Using the sample data of Shanghai and Shenzhen A-share listed companies, this paper empirically tests the impact of stock price information content on corporate innovation and its internal mechanism. The study found that the information content of stock prices has a significant role in promoting corporate innovation. An increase of 1 percentage point in the information content of stock prices will increase the number of patent applications by companies in the next year by 1.13 percentage points, and this effect is demonstrated in private enterprises and high-tech companies. Further analysis shows that the internal mechanism of this effect is: the increase in the stock price information content allows managers to obtain more useful information from the stock price, which is conducive to the development of innovative activities; the increase in the stock price information content promotes stock liquidity, which has helped strengthen the institutional investor supervision mechanism and improved the internal innovation incentives of enterprises.
\end{abstract}

\section{Keywords}

Stock Price Information Content, Feedback Effect, Enterprise Innovation

\section{Introduction}

One of the basic functions of the capital market is to use changes in stock prices to aggregate and reflect a variety of information. Changes in stock prices not only reflect the information that managers have about the company, but also reflect investors' views and private information on the fundamentals of the company and the industry in which they operate. This information can provide a valuable reference for managers to make decisions and guide managers to effec- 
tively allocate corporate resources. This function of the capital market is called the stock price feedback effect. With the implementation of the Securities Law in 1999, the completion of the share-trading reform in 2006, and the introduction of short-selling mechanisms such as stock index futures, margin trading, and options in recent years, the information efficiency of my country's stock market has also improved significantly. In this context, from the perspective of feedback effects, studying the impact mechanism and effect of the capital market on the decision-making of listed companies has important practical significance for improving the efficiency of the stock market, optimizing the decision-making of listed companies, and deepening the role of the capital market in serving the real economy.

As an important part of the financial system, the stock market has always been concerned by the industry and academia for its role in corporate innovation. Existing research can be divided into "financing theory" and "incentive theory", and pay less attention to the "feedback effect" of the stock market on corporate innovation. In addition to providing funds and forming incentives for corporate innovation, the stock market can also provide information feedback. The information feedback function means that the stock market gathers and transmits all kinds of information through the stock price. When the stock price contains the private information of external investors that the corporate manager does not know beforehand, the manager can obtain new information from the company's stock price changes to adjust and optimize the company's resource allocation and R\&D investment decision. Because the failure rate of corporate innovation is higher than that of traditional investment projects, managers must use useful information in stock prices.

This paper uses the patent application database of the CSMAR Database and the sample data of listed companies in the A-share market from 2009 to 2018 to empirically test the feedback effect of stock price information content on corporate innovation and its internal mechanism. The research contributions of this paper are shown in two points: First, the research on the stock market feedback effect at home and abroad mainly focuses on corporate investment behavior, and there is little research on corporate innovation; second, this paper further explores the difference in the impact of stock price information on corporate innovation qualitative and internal mechanism. Based on the previous views, this paper mainly carries out research, carries out theoretical analysis and research hypothesis, and verifies the hypothesis through empirical analysis and draws the final conclusion.

\section{Literature Review and Research Hypothesis}

\subsection{Literature Review}

\subsubsection{Research on the Impact of the Stock Market on Corporate Innovation}

Regarding the impact of the stock market on corporate innovation, research can be divided into two groups of views. The "financing theory" believes that the 
funds provided by the stock market are more stable than credit funds, and are more compatible with the characteristics of long $\mathrm{R} \& \mathrm{D}$ investment cycles, high adjustment costs, and uncertain returns. Therefore, equity financing has become an important source of funds for corporate innovation. Brown et al. (2009) used US corporate data to study and show that for emerging high-tech companies with a relatively short establishment, the main sources of capital for corporate R\&D investment are cash flow and equity financing. Brown et al. (2013) used data from 32 countries and found that countries with stronger shareholder protection and easier access to the stock market have higher corporate R\&D investment. Hsu et al. (2014) used cross-country data to study and found that industries that rely more on external financing and high-tech-intensive industries show higher innovation capabilities in countries with more developed stock markets. Xiao and Zhao (2012) used international data to study and found that compared with the development of the banking sector, the development of the stock market has a significant role in promoting technological innovation of enterprises. Hu Hengqiang et al. (2020) found that endogenous financing and equity financing can significantly promote enterprise innovation investment.

Ferreira et al. (2104) found the "incentive theory" that the decentralization of control and the change of governance mechanism caused by the listing of enterprises will reduce the innovation activities of enterprises. After a company is listed, managers are under pressure from the capital market and tend to choose traditional investment projects with stable cash flow and relatively low risks, making it easier to convey good corporate information to investors instead of choosing uncertain returns, long periods, and high-risk innovative projects. Bernstein (2015) found that a large number of inventors left the company after the company went public, which reduced the quality of internal innovation of the company, but after the company went public, it attracted new human capital, thereby obtaining external innovation and changing the company's innovation strategy. Kong Dongmin et al. (2015) used total factor productivity to measure innovation efficiency. Based on the data of listed companies in China, they found that after companies went public, total factor productivity declined. They explained from the perspective of "incentive theory" and found that manager incentives, information disclosure incentives and the changes in inventor incentives have led to a decline in corporate innovation behavior. Fang et al. (2014) found that the increase in stock liquidity significantly reduced the innovation output of enterprises. The reason is that the increase in liquidity leads to an increase in the risk of hostile takeovers and the emergence of more institutional investors who are not actively collecting information and monitoring.

\subsubsection{The Feedback Effect of the Stock Market on Corporate Decisions}

A series of domestic and foreign documents have studied the feedback effect of the stock market, mainly focusing on the analysis of the information content of the stock price on corporate investment behavior. Dow and Gorton (1997) theoretically explained the impact of stock price information content on corporate 
investment behavior. Durnev et al. (2004) showed through empirical tests that corporate investment efficiency and stock price information content show a significant positive relationship. Chen et al. (2007) found that managers can obtain useful private information from stock prices, which is beneficial to optimize corporate investment behavior. Yang Jiwei and Nie Shunjiang (2010) show that the increase in the information content of stock prices can effectively curb overinvestment by enterprises and effectively alleviate underinvestment by enterprises. Yu Lifeng et al. (2014) found that the information content of stock prices can significantly increase the sensitivity of a company's investment stock price, that is, stock price information can improve the investment efficiency of a company. Chen Kang and Liu Qi (2018), Pang Jiaren et al. (2019) used margin trading as an exogenous shock variable for the information content of stock prices and obtained similar conclusions.

There are few literatures on the relationship between the stock market and corporate innovation from the perspective of feedback effects. Mathers et al. (2016) found that the higher the information content of stock prices, the higher the innovation output of enterprises. When corporate managers have less experience in optimal innovation strategies or face greater risks, the information content of stock prices is more important for corporate innovation. Research by Li Qijia et al. (2020) has shown that the information content of stock prices can effectively guide the allocation and use of corporate innovation resources, thereby significantly improving corporate innovation capabilities.

To sum up, the relevant literature in the early stage shows the following two characteristics: First, the research on the stock market and corporate innovation is mainly carried out from the "financing theory" and "incentive theory", and the impact on corporate innovation from the perspective of the stock price feedback effect. There are few studies; second, the research on the feedback effect of the stock market on corporate decision-making mainly focuses on corporate investment behavior, and there is less literature focusing on corporate innovation behavior.

\subsection{Theoretical Analysis and Research Hypothesis}

This article believes that the information content of stock prices affects corporate innovation through two mechanisms: strengthening manager learning and improving stock liquidity.

\subsubsection{Manager Learning Mechanism}

One of the basic functions of the stock market is to optimize the allocation of resources so that the funds of external investors can flow to companies with better business performance and more promising future development. To achieve this optimization function, the premise is that the stock market can gather and transmit a variety of information through stock prices. When the stock price contains private information of external investors that the manager does not know, the manager can obtain new information from the stock price, which is 
conducive to making better decisions. This mechanism is called "manager learning" mechanism. This new information includes future market demand for enterprise products, future investment opportunities, future financing possibilities, relationships with various stakeholders, and competitive strategies with rival companies. Since the success rate of corporate innovation is lower and higher risk than traditional investment projects, managers must use this useful information when making innovative investment decisions. Therefore, it is expected that the increase in stock price information can promote corporate innovation.

\subsubsection{Stock Liquidity Mechanism}

The increase in the information content of stock prices can attract more investors to participate in transactions, thereby improving stock liquidity. Chen Menggen and Mao Xiaoyuan (2007) showed that there is a significant positive correlation between stock turnover rate and stock price information content. Furthermore, the improvement of stock liquidity can bring more traders' information into the stock price, which helps to increase the stock price information content (Su \& Xiong, 2013). It can be said that the information content of stock prices and stock liquidity promote each other.

Enterprise innovation is a systematic project, which requires a good institutional environment and incentive mechanism as a guarantee. Many documents show that a good corporate governance mechanism can promote enterprise technological innovation (Lu \& Dang, 2014). The increase in stock liquidity will help strengthen the supervision mechanism of institutional investors and reduce the opportunistic tendency of corporate managers (Faure-Grimaud \& Gromb, 2004). The increase in stock price information content and stock liquidity will also help more traders gather information in the stock price, enabling stakeholders to provide managers with more effective compensation contracts, thereby inspiring managers' enthusiasm for work (Jayaraman \& Milbourn, 2012). Therefore, the increase of stock price information content can improve corporate agency efficiency, improve corporate governance mechanisms, and ultimately promote corporate innovation through stock liquidity.

Based on the above analysis, this article proposes the following hypotheses:

Hypothesis 1: The stock market has a significant feedback effect on corporate innovation, that is, the increase of stock price information content has a significant positive promotion effect on corporate innovation.

Hypothesis 2: Strengthening the learning of managers is the internal mechanism by which the information content of stock prices affects corporate innovation.

Hypothesis 3: Improving stock liquidity is the internal mechanism for the information content of stock prices to influence corporate innovation.

Compared with private enterprises, there is a natural connection between state-owned enterprises and the government, so the government intervention is also greater. The transformation and restructuring of state-owned enterprises is still in progress. The appointment of corporate managers is determined by the 
higher-level government management departments. The managers themselves have administrative ranks. Political promotion incentives determine that managers are subordinate to their superiors. Therefore, the behavior of managers is to take politics as the main orientation, not the market as the main orientation (Xu \& Yan, 2011). State-owned enterprises also bear policy burdens and social burdens due to historical inheritance and the nature of the enterprise. Target assessment cannot be completely measured by market performance indicators. Due to these political tasks, state-owned enterprises can receive government financial subsidies. In addition, state-owned banks have a natural preference for state-owned enterprises when issuing loans, and there are also soft constraints on state-owned enterprise budgets (Lin \& Li, 2004). The dominance of state-owned shares is common, and it is difficult for external institutional investors to form checks and balances. State-owned enterprises have multi-level principal-agent relationships, and the absence of owners makes it difficult to design effective supervision mechanisms for managers. Human behavior is supervised (Li, 2007). All in all, due to the natural connection with the government, the degree of marketization of state-owned enterprises is not as good as that of private enterprises in the competitive market, and the feedback effect of stock price information content is weaker in state-owned enterprises. Therefore, the information content of state-owned enterprises' stock price has an impact on enterprise innovation. The role of promotion is weaker than that of private enterprises. High-tech companies choose to go public for financing more, and the changes in stock prices and the information content contained in stock prices are also more concerned by high-tech companies. Therefore, the feedback effect has a greater impact on high-tech companies.

Based on the above analysis, this article proposes the following hypotheses:

Hypothesis 4: Compared with state-owned enterprises, the information content of stock prices has a more significant role in promoting innovation in private enterprises.

Hypothesis 5: Compared with non-high-tech companies, the information content of stock prices plays a more significant role in promoting the innovation of high-tech companies.

To verify the above five assumptions, this paper mainly adopts the following verification methods. Firstly, the Poisson distribution regression model in the counting model is used to test the influence of stock price information content on enterprise innovation, that is, to verify hypothesis 1; Secondly, using the measurement method of Fresard (2012) for reference to test the "manager learning mechanism", thus verifying hypothesis 2 ; Then, using the viewpoints of Amihud and Mendelson (1986), Su Dongwei and Xiong Jiacai (2013) for reference, we use illiquidity indicators to measure stock liquidity and test the "stock liquidity mechanism", thus verifying hypothesis 3 ; In addition, by establishing a model to calculate the stock price information content, comparing the regression coefficient of state-owned and private enterprise samples and testing the significance of coefficient difference by self-sampling method, hypothesis 4 is veri- 
fied; Finally, by analyzing the regression results of the model and comparing the coefficient of stock price information content between high-tech and non-high-tech companies, the hypothesis 5 is verified.

\section{Data, Models and Variables}

\subsection{Data Source}

The patent data in this article comes from the "listed company patent research database" of CSMAR, the corporate R\&D data comes from the Tonghuashun Database, and the institutional investor data comes from the Wind Database. The rest of the sample data comes from the CSMAR Database. Since corporate $R \& D$ has only started to have complete data in 2009 , the research interval of this article is set to 2009-2018. In order to ensure the reliability of the research results, the samples of ST \& PT companies, financial industry samples, IPO samples and variables with missing values were excluded, and the main variables were reduced by $1 \%$. The final sample number is 8786 , and the number of enterprises is 1891 .

For these three databases, CSMAR Economic and Financial Research Database is an economic and financial database developed by Tai'an from the academic research needs, drawing on the professional standards of CRSP of Chicago University, Compustat of Standard \& Poor's, TAQ of New York Stock Exchange, I/B/E/S, Thomson and other internationally renowned databases, and combining with China's actual national conditions. Tonghuashun Database is a software system that provides research and investment decision-making services. Its core functions include multidimensional information of different financial varieties, several macro industry databases, and research tools such as asset management system and valuation model. Wind Database is a service provider of financial data and analysis tools. In the field of financial data, Wind Information has built a first-class large-scale financial engineering and financial data warehouse with financial securities data as the core in China. A large number of Chinese and English media, research reports, academic papers, etc. often quote the data provided by Wind Information.

\subsection{Model Setting}

This article uses the number of patent applications to measure the innovation capability of an enterprise. The distribution of patent data is the Poisson distribution, so for reference Yuan Jianguo et al. (2015), the Poisson distribution regression model in the counting model is used to test the impact of stock price information content on corporate innovation.

$$
E\left(\text { Patent }_{i, t+n} \mid x_{i t}\right)=\exp \left(\alpha+\beta_{1} \operatorname{Inform}_{i t}+\sum_{i=1}^{k} \gamma_{i} x_{i t}+\varepsilon_{i t}\right)
$$

Among them, Patent ${ }_{i, t+n}$ is the number of patent applications for the explained variable, $n$ takes 1,2 , and 3 years respectively, Inform $_{i t}$ is the stock price in- 
formation content of the explanatory variable, $x_{i t}$ is a series of control variables, and $\varepsilon_{i t}$ is the disturbance term.

Since patent application variables contain more zero values, it is more reasonable to use Zero-inflated Poisson Regression. At the same time, Vuong statistics are used to test the reliability of the regression method (Vuong, 1989). If the Vuong statistic is greater than 1.96, the zero-inflated Poisson regression model should be selected; conversely, if the Vuong statistic is small (or negative), the standard Poisson regression model should be selected. The software used for empirical estimation is Stata 13.0.

\subsection{Definition of Variables}

\subsubsection{Explained Variable: Corporate Innovation}

Domestic literature mostly uses R\&D expenditure as an indicator to measure the innovation capability of enterprises. This indicator is an indicator of innovation input and does not reflect the output and quality of innovation well. Some scholars have shown that the use of patent application indicators can better measure the R\&D and innovation capabilities of enterprises (Seiu, 2014). Foreign literature often uses the number of patent applications and patent citations to measure corporate innovation capabilities. Since my country's patent citation data is not yet available, this article uses the number of patent applications to measure corporate innovation. CSMAR's "Listed Company Patent Research Database" contains the number of applications and authorizations for invention patents, utility model patents, and design patents each year. By adding up the three types of patents, we get the total number of patent applications and authorizations for each company each year. This article uses the total number of patent applications for the basic test, and the total number of patents granted for the robustness test. At the same time, invention patents are the most important of the three patents, so the robustness test is also carried out based on the number of invention patent applications.

\subsubsection{Explanatory Variable: Information Content of Stock Price}

The information entered into the stock price includes information at the market, industry, and corporate level. In order to obtain the corporate characteristics contained in the stock price, it is necessary to remove the market-level and industry-level influence. Therefore, when using the index model, it is necessary to add the factors of market return and industry return. Drawing on the relevant literature in the previous period, the following model is used to calculate the stock price information content:

$$
r_{i t}=\alpha_{i}+\beta_{1 i} r_{m t}+\beta_{2 i} r_{j t}+\varepsilon_{i t}
$$

Among them, $r_{i t}$ is the weekly return rate of stock $i$ in period $t, r_{m t}$ is the weekly market return rate in period $t, r_{j t}$ is the weekly return rate of industry $j$ in period t to which stock $i$ belongs, and $\varepsilon_{i t}$ is the residual. The goodness of fit is $R_{i t}^{2}$ and $1-R_{i t}^{2}$ represents the influence of the company's characteristic 
information on the change in the stock $i$ return rate. Inform $_{i t}$ can be defined as:

$$
\text { Inform }_{i t}=\ln \left[\frac{\left(1-R_{i t}^{2}\right)}{R_{i t}^{2}}\right]
$$

\section{Empirical Result Analysis}

\subsection{Basic Regression Results}

The first column of Table 1 reports the basic results obtained using the zero-inflated Poisson estimation method. The explained variable uses the number of patent applications of the company in the next year. The last two lines are the Vuong test statistics and $p$-values. The $p$-values are all less than 0.01 , indicating that it is reasonable to use the zero-inflated Poisson regression model for the sample data. The regression coefficient of the stock price information content Inform is significantly positive at the statistical level of $1 \%$, and the coefficient is 0.12 , indicating that the stock price information content increases by 1 percentage point, and the number of patent applications for the next year will increase by $e^{0.12}$ percentage points, which is 1.13 percentage points. The regression results show that the stock price information content has a significant positive impact on the number of patent applications of a company in the next year, which also means that the stock price information content has a significant role in promoting corporate innovation. Hypothesis 1 proposed in the previous article has been verified. The regression results of the control variables are generally consistent with existing studies. The coefficients of R\&D expenditure, scale, profitability, and company years are significantly positive, indicating that the larger these variables, the more patent applications a company has. The coefficient of the dummy variable of state-owned enterprises is significantly negative, which means that on average, the number of patent applications of state-owned enterprises is lower than that of private enterprises.

Next, the internal mechanism of the influence of stock price information content on corporate innovation is tested. First test the "Manager Learning Hypothesis". This hypothesis means that managers can obtain new information from stock prices, thereby promoting corporate innovation. The corporate characteristic information contained in the stock price may contain the information that the corporate manager has already mastered. This part of the information will obviously not have a new impact on the manager's decision-making. If the information known to the manager can be separated, the "manager learning hypothesis" can be tested. Drawing on the measurement method of Fresard (2012), two variables are used to measure the known information of managers: the number of analysts and analyst earnings forecast deviation. The larger the number of analysts, the more analysts can mine the information known by the managers, and it also means the higher the transparency of the company's information. The definition of analyst earnings forecast deviation is as follows: the standard deviation of the last earnings forecast of all analysts in the same company 
Table 1. Zero-inflated Poisson regression results.

\begin{tabular}{|c|c|c|c|c|}
\hline & (1) & (2) & (3) & (4) \\
\hline Inform & $\begin{array}{c}0.120^{* * *} \\
(37.66)\end{array}$ & $\begin{array}{c}0.123^{* * *} \\
(37.23)\end{array}$ & $\begin{array}{c}0.124^{* * *} \\
(36.73)\end{array}$ & $\begin{array}{c}1.676^{* * *} \\
(37.77)\end{array}$ \\
\hline Inform $\times$ ILLIQ & & & & $\begin{array}{c}0.086^{* * *} \\
(34.89)\end{array}$ \\
\hline $\mathrm{RD}$ & $\begin{array}{c}2.158^{\star * *} \\
(23.10)\end{array}$ & $\begin{array}{l}1.964^{* * *} \\
(20.65)\end{array}$ & $\begin{array}{c}2.154^{* * *} \\
(21.96)\end{array}$ & $\begin{array}{c}2.534^{\star * *} \\
(27.26)\end{array}$ \\
\hline Tobin & $\begin{array}{l}0.004 \\
(1.48)\end{array}$ & $\begin{array}{c}-0.026^{* * *} \\
(-10.07)\end{array}$ & $\begin{array}{c}-0.013^{\star * *} \\
(-5.24)\end{array}$ & $\begin{array}{c}-0.070^{\star * *} \\
(-26.03)\end{array}$ \\
\hline Cash & $\begin{array}{c}-0.838^{\star * *} \\
(-38.78)\end{array}$ & $\begin{array}{c}-0.943^{* * *} \\
(-42.17)\end{array}$ & $\begin{array}{c}-1.061^{\star * *} \\
(-46.34)\end{array}$ & $\begin{array}{c}-0.619^{* * *} \\
(-28.39)\end{array}$ \\
\hline Lev & $\begin{array}{c}-0.034^{\star *} \\
(-2.29)\end{array}$ & $\begin{array}{l}0.003 \\
(0.21)\end{array}$ & $\begin{array}{l}-0.030^{*} \\
(-1.92)\end{array}$ & $\begin{array}{c}0.154^{* * *} \\
(10.33)\end{array}$ \\
\hline Capital & $\begin{array}{c}1.765^{\star * *} \\
(45.31)\end{array}$ & $\begin{array}{c}1.849^{* * *} \\
(46.30)\end{array}$ & $\begin{array}{c}1.749^{* * *} \\
(43.51)\end{array}$ & $\begin{array}{c}1.485^{\star * *} \\
(37.52)\end{array}$ \\
\hline Size & $\begin{array}{l}0.932^{* * *} \\
(401.18)\end{array}$ & $\begin{array}{l}0.878^{\star * *} \\
(323.30)\end{array}$ & $\begin{array}{l}0.923^{\star * *} \\
(367.59)\end{array}$ & $\begin{array}{l}0.705^{\star * *} \\
(190.71)\end{array}$ \\
\hline ROE & $\begin{array}{c}1.589^{* * *} \\
(59.86)\end{array}$ & $\begin{array}{c}1.194^{* * *} \\
(40.80)\end{array}$ & $\begin{array}{c}1.649^{* * *} \\
(57.87)\end{array}$ & $\begin{array}{c}1.087^{* * *} \\
(40.89)\end{array}$ \\
\hline Age & $\begin{array}{c}0.026^{\star * \star} \\
(50.44)\end{array}$ & $\begin{array}{c}0.031^{* \star *} \\
(57.30)\end{array}$ & $\begin{array}{c}0.034^{\star * *} \\
(61.05)\end{array}$ & $\begin{array}{c}0.025^{\star * \star} \\
(47.89)\end{array}$ \\
\hline Nature & $\begin{array}{c}-0.294^{* * *} \\
(-60.01)\end{array}$ & $\begin{array}{c}-0.223^{\star * *} \\
(-42.95)\end{array}$ & $\begin{array}{c}-0.288^{\star * *} \\
(-55.63)\end{array}$ & $\begin{array}{c}-0.256^{\star \star *} \\
(-52.08)\end{array}$ \\
\hline Inst & $\begin{array}{c}0.840^{* * *} \\
(76.97)\end{array}$ & $\begin{array}{c}0.776^{\star * *} \\
(67.89)\end{array}$ & $\begin{array}{c}0.867^{\star * *} \\
(74.08)\end{array}$ & $\begin{array}{c}1.020^{* * *} \\
(89.03)\end{array}$ \\
\hline Analyst & & $\begin{array}{c}0.167^{\star \star \star} \\
(41.45)\end{array}$ & & \\
\hline DSP & & & $\begin{array}{c}0.004^{* * *} \\
(3.26)\end{array}$ & \\
\hline ILLIQ & & & & $\begin{array}{c}-0.336^{* * *} \\
(-84.29)\end{array}$ \\
\hline Industry effect & Control & Control & Control & Control \\
\hline Annual effect & Control & Control & Control & Control \\
\hline $\mathrm{N}$ & 8786 & 7053 & 5869 & 8786 \\
\hline Voung & 15.912 & 14.492 & 13.801 & 15.773 \\
\hline$p$ & 0.000 & 0.000 & 0.000 & 0.000 \\
\hline
\end{tabular}

in the same year divided by the absolute value of the forecast mean. In order to make the results easier to analyze, add 0.0001 to the analyst's earnings forecast deviation and then take the natural logarithm. In this way, the higher the variable, the more private information the market has on managers. After adding the information variables held by the analyst, if the regression coefficient of the stock price information content is still significant, it means that there is still new information in the stock price that has an impact on the manager's deci- 
sion-making behavior. The second and third columns of Table 1 report the regression results. The second column adds the variable of the number of analysts, and the third column adds the divergent variable of analyst earnings forecast. It can be seen from the results that the regression coefficients of the variables Analyst and DSP are both significantly positive, indicating that the higher the degree of information transparency, the higher the number of enterprise patent applications. This means that the more transparent the information, the more it is necessary for companies to apply for patents to protect their research and development results. The regression coefficient of the stock price information content variable is still significantly positive, thus verifying Hypothesis 2 .

Second, test the "stock liquidity hypothesis". The increase in the information content of stock prices has attracted more investors to participate in stock transactions, which has led to an increase in stock liquidity. The increase in stock liquidity will help strengthen the institutional investor supervision mechanism, optimize managers to provide more effective compensation contracts, reduce the opportunistic tendency of corporate managers, improve corporate governance mechanisms, and form effective incentives for corporate executives and employees, Thereby promoting enterprise innovation. Drawing lessons from Amihud and Mendelson (1986), Su Dongwei and Xiong Jiacai (2013), illiquidity indicators are used to measure stock liquidity. The indicator is defined as follows:

$$
\mathrm{ILLIQ}_{\mathrm{it}}=\frac{1}{D_{i t}} \sum_{d=1}^{D_{i t}}\left(\frac{\left|r_{i t d}\right|}{V_{i t d}}\right) \times 100
$$

Among them, $r_{i t d}$ and $V_{i t d}$ are the return rate and transaction amount of stock $i$ on the d day of t year ignoring the reinvestment of dividends; $D_{i t}$ is the total number of trading days in the year; $\left|\mathrm{r}_{\text {itd }}\right| / V_{\text {itd }}$ is the price change caused by the turnover per million yuan, taking the annual average and multiplying by 100 is the illiquidity index. The higher the ILLIQ, the greater the impact of the unit transaction amount on the price, and the lower the stock liquidity, and vice versa.

Next, add the stock illiquidity index (ILLIQ) and the interaction term (Inform $\times$ ILLIQ) between the index and the information content of the stock price in the regression model. The fourth column of Table 1 reports the regression results. The stock illiquidity coefficient is significantly negative, indicating that the higher the stock liquidity, the greater the number of patent applications for companies in the next year. The coefficient of the interaction term is significantly positive, indicating that the lower the stock liquidity, the greater the impact of the stock price information content on the number of patent applications, that is, the stock price information content promotes corporate innovation activities by improving stock liquidity. Stock liquidity is the internal mechanism by which the information content of stock prices affects corporate innovation. Assumption 3 is verified.

\subsection{Grouped Regression Results}

Next, test Hypothesis 4 and Hypothesis 5. The results of group regression are 
shown in Table 2. The first and second columns of Table 2 are grouped according to the nature of the property rights of the enterprises, and the state-owned enterprises and private enterprises are respectively regressed, and the dummy variables of the state-owned enterprises are removed from the model. The stock price information content inform is significantly positive, but the regression coefficient of the private enterprise sample is significantly larger. Further use the self-sampling method to test the significance of the difference in coefficients. The empirical $p$ value in the last row is 0.000 , which indicates that the coefficients are significantly different. That is, compared with state-owned enterprises, the information content of stock prices is more important for private enterprises in the next year. The number of applications has a greater promotion effect, and Hypothesis 4 has been verified.

The third and fourth columns in Table 2 are the results of the regression of high-tech companies and non-high-tech companies. The industry classification

Table 2. Group regression results.

\begin{tabular}{|c|c|c|c|c|}
\hline & $\begin{array}{l}\text { (1) State-owned } \\
\text { enterprise }\end{array}$ & $\begin{array}{l}\text { (2) Private } \\
\text { Enterprise }\end{array}$ & $\begin{array}{l}\text { (3) High-tech } \\
\text { Companies }\end{array}$ & $\begin{array}{l}\text { (4) Non-high-tech } \\
\text { companies }\end{array}$ \\
\hline Inform & $\begin{array}{l}0.035^{\star * *} \\
(34.93)\end{array}$ & $\begin{array}{c}0.236^{\star * *} \\
(49.14)\end{array}$ & $\begin{array}{l}0.342^{\star * *} \\
(51.71)\end{array}$ & $\begin{array}{c}0.031^{\star * *} \\
(8.27)\end{array}$ \\
\hline $\mathrm{RD}$ & $\begin{array}{l}16.170^{* * *} \\
(131.87)\end{array}$ & $\begin{array}{l}9.167^{\star * *} \\
(80.59)\end{array}$ & $\begin{array}{c}6.473^{\star * *} \\
(55.65)\end{array}$ & $\begin{array}{l}9.913^{\star * *} \\
(71.57)\end{array}$ \\
\hline Tobin & $\begin{array}{l}-0.091^{* * *} \\
(-23.73)\end{array}$ & $\begin{array}{c}0.021^{\star * *} \\
(7.14)\end{array}$ & $\begin{array}{c}-0.015^{\star * *} \\
(-4.39)\end{array}$ & $\begin{array}{l}-0.106^{\star * *} \\
(-33.35)\end{array}$ \\
\hline Cash & $\begin{array}{c}-0.169^{* * *} \\
(-5.70)\end{array}$ & $\begin{array}{c}0.624^{\star * *} \\
(21.76)\end{array}$ & $\begin{array}{c}-1.469^{\star * *} \\
(-40.80\end{array}$ & $\begin{array}{c}0.144^{* * *} \\
(5.53)\end{array}$ \\
\hline Lev & $\begin{array}{c}-1.173^{* * *} \\
(-65.64)\end{array}$ & $\begin{array}{l}1.251^{\star * *} \\
(52.67)\end{array}$ & $\begin{array}{c}-0.376^{* * *} \\
(-14.37)\end{array}$ & $\begin{array}{c}-0.654^{* * *} \\
(-38.02)\end{array}$ \\
\hline Capital & $\begin{array}{c}2.693^{\star * *} \\
(54.98)\end{array}$ & $\begin{array}{c}-1.586^{* * *} \\
(-24.30)\end{array}$ & $\begin{array}{c}0.206^{* * *} \\
(3.46)\end{array}$ & $\begin{array}{l}1.701^{\star * *} \\
(33.76)\end{array}$ \\
\hline Size & $\begin{array}{l}0.961^{* * *} \\
(301.56)\end{array}$ & $\begin{array}{l}0.915^{\star * *} \\
(257.77)\end{array}$ & $\begin{array}{l}1.239 * * * \\
(302.17)\end{array}$ & $\begin{array}{l}0.796^{* * *} \\
(269.62)\end{array}$ \\
\hline ROE & $\begin{array}{l}1.376^{\star * \star} \\
(39.38)\end{array}$ & $\begin{array}{l}1.949^{\star * \star} \\
(52.41)\end{array}$ & $\begin{array}{l}0.006 \\
(0.13)\end{array}$ & $\begin{array}{l}2.849^{\star * *} \\
(89.10)\end{array}$ \\
\hline Age & $\begin{array}{c}0.066^{\star \star *} \\
(92.75)\end{array}$ & $\begin{array}{l}-0.025^{\star * \star} \\
(-34.42)\end{array}$ & $\begin{array}{c}-0.016^{* * *} \\
(-15.50)\end{array}$ & $\begin{array}{l}0.029^{\star * *} \\
(48.44)\end{array}$ \\
\hline Natural & & & $\begin{array}{l}-0.105^{\star * *} \\
(-12.33)\end{array}$ & $\begin{array}{l}-0.264^{* * *} \\
(-42.45)\end{array}$ \\
\hline Inst & $\begin{array}{l}0.915^{\star * *} \\
(59.89)\end{array}$ & $\begin{array}{c}0.841^{\star * *} \\
(54.37)\end{array}$ & $\begin{array}{l}1.481^{\star * *} \\
(68.80)\end{array}$ & $\begin{array}{c}0.947^{\star * *} \\
(71.78)\end{array}$ \\
\hline Industry effect & Control & Control & Control & Control \\
\hline Annual effect & Control & Control & Control & Control \\
\hline $\mathrm{N}$ & 3746 & 5040 & 1654 & 7132 \\
\hline Voung & 11.953 & 15.521 & 5.959 & 19.228 \\
\hline$p$ & 0.000 & 0.000 & 0.000 & 0.000 \\
\hline
\end{tabular}


used in this article uses category classification except for the manufacturing industry. Companies in the electronic components, biomedicine, and electronic communications industries are regarded as high-tech companies, while the rest are non-high-tech companies. A total of 1654 samples of high-tech companies have entered the regression, and a sample of 7132 non-high-tech companies. In the regression results of the two sets of samples, the coefficient of the stock price information content is significantly positive, but the former coefficient is 0.342 , indicating that the stock price information content increases by 1 percentage point, and the number of patent applications for high-tech companies in the next year will increase by $e^{0.342}$ percentage points which is about 1.4 percentage points. In contrast, the information content coefficient of non-high-tech companies' stock prices is 0.031 . The empirical $p$ value for the significance test of the difference between the two coefficients is 0.000 , which means that compared with non-high-tech companies, the share price information content has a greater role in promoting the innovation of high-tech companies. Hypothesis 5 has been verified.

\section{Conclusion and Policy Implications}

This paper uses the sample data of my country's Shanghai and Shenzhen A-share listed companies from 2009 to 2018 to study the feedback effect of corporate characteristics contained in stock prices on corporate innovation and its internal mechanism. Research shows that: 1) The stock price information content will significantly promote the number of patent applications for companies in the next 1 to 3 years. If the stock price information content increases by 1 percentage point, the number of patent applications in the next year will increase by 1.13 percentage points; 2) The impact of stock price information content on corporate innovation is mainly realized by strengthening the manager's learning mechanism and improving the stock liquidity mechanism; 3) Compared with state-owned enterprises, the positive impact of stock price information content on private enterprise innovation is more significant; 4) Compared with non-high-tech companies, the information content of stock prices has a greater positive impact on high-tech companies.

The research conclusions of this paper have important policy implications for deepening and perfecting the effectiveness of my country's stock market and promoting corporate innovation. First, the stock market has an important feedback effect on corporate innovation. The higher the stock price information content, the more useful information managers can obtain from the stock price; at the same time, the higher the stock price information content, it will attract more investors to participate in transactions, improve stock liquidity, and strengthen the company's external governance mechanism. There by promoting enterprise innovation. Therefore, we must continue to advance the reform of my country's stock market, improve the transparency of the stock market, and improve the effectiveness of the stock market, so that stock prices can better reflect 
corporate characteristics. For example, improve the market information transmission system and improve the efficiency of information disclosure, dissemination, interpretation and feedback. Second, improve the competitive environment between state-owned and private enterprises, reduce government interventions in state-owned enterprises, introduce private and foreign capital, and continue to promote the reform of mixed ownership of state-owned enterprises, so that market mechanisms can be more decisive in resource allocation role, and strengthen the mechanism and ability of state-owned enterprises to obtain information from the stock market.

\section{Deficiencies of Articles}

The deficiency of this paper is that the data of patent citation in China is not available yet, and only the number of patent applications is used to measure the innovation ability of enterprises, so the research has limitations.

\section{Conflicts of Interest}

The authors declare no conflicts of interest regarding the publication of this paper.

\section{References}

Amihud, Y., \& Mendelson, H. (1986). Asset Pricing and the Bid-Ask Spread. Journal of Financial Economics, 17, 223-249. https://doi.org/10.1016/0304-405X(86)90065-6

Bernstein, S. (2015). Does Going Public Affect Innovation? Journal of Finance, 70, 1365-1403. https://doi.org/10.1111/jofi.12275

Brown, J. R., Fazzari, S. M., \& Petersen, B. C. (2009). Financing Innovation and Growth: Cash Flow, External Equity, and the 1990s R\&D Boom. Journal of Finance, 64, 151-185. https://doi.org/10.1111/j.1540-6261.2008.01431.x

Brown, J. R., Martinsson, G., \& Petersen, B. C. (2013). Law, Stock Markets, and Innovation. The Journal of Finance, 68, 1517-1549. https://doi.org/10.1111/jofi.12040

Chen, K., \& Liu, Q. (2018). Stock Price Information Content and Investment-Stock Price Sensitivity: A Quasi-Natural Experiment Based on Margin Financing and Securities Lending. Financial Research, No. 9, 126-142.

Chen, M. G., \& Mao, X. Y. (2007). Information Content of Stock Prices and Market Trading Activity. Financial Research, No. 3, 125-139.

Chen, Q., Goldstein, I., \& Wei, J. (2007). Price Informativeness and Investment Sensitivity to Stock Price. Review of Financial Studies, 20, 619-650. https://doi.org/10.1093/rfs/hhl024

Dow, J., \& Gorton, G. (1997). Stock Market Efficiency and Economic Efficiency: Is There a Connection? Journal of Finance, 52, 1087-1129. https://doi.org/10.1111/j.1540-6261.1997.tb02726.x

Durnev, A., Morck, R., \& Yeung, B. (2004). Value-Enhancing Capital Budgeting and Firm-Specific Stock Return Variation. The Journal of Finance, 59, 65-105. https://doi.org/10.1111/j.1540-6261.2004.00627.x

Fang, V. W., Tian, X., \& Tice, S. (2014). Does Stock Liquidity Enhance or Impede Firm Innovation? Journal of Finance, 69, 2085-2125. https://doi.org/10.1111/jofi.12187 
Faure-Grimaud, A., \& Gromb, D. (2004). Public Trading and Private Incentives. Review of Financial Studies, 2, 75-102. https://doi.org/10.1093/rfs/hhh002

Ferreira, D., Manso, G., \& Silva, A. C. (2014). Incentives to Innovate and the Decision to go Public or Private. Review of Financial Studies, 27, 257-300. https://doi.org/10.1093/rfs/hhs070

Fresard, L. (2012). Cash Savings and Stock Price Informativeness. Review of Finance, 16, 985-1012. https://doi.org/10.1093/rof/rfr004

Hsu, P.-H., Tian, X., \& Xu, Y. (2014). Financial Development and Innovation: Cross-Country Evidence. Journal of Financial Economics, 112, 116-135. https://doi.org/10.1016/j.jfineco.2013.12.002

Hu, H. Q., Fan, C., \& Du, Q. (2020). Financing Structure, Financing Constraints and Corporate Innovation Investment. China Economic Issues, No. 1, 27-41.

Jayaraman, S., \& Milbourn, T. T. (2012). The Role of Stock Liquidity in Executive Compensation. Accounting Review, 87, 537-563. https://doi.org/10.2308/accr-10204

Kong, D. M., Wang, Y. N., \& Dai, Y. H. (2015). Why Does the Listing of Companies Reduce Production Efficiency? A Study from the Perspective of Institutional Incentives. Financial Research, No. 2, 76-97.

Li, Q. J., Luo, F. K., \& Pang, T. Y. (2020). Listening to Zeming: The Innovative Guidance Effect of Stock Information. Journal of Shanxi University of Finance and Economics, No. 2, 16-28.

Li, S. X. (2007). Property Rights, Agency Costs and Agency Efficiency. Economic Research, No. 1, 102-113.

Lin, Y. F., \& Li, Z. Y. (2004). Policy Burden, Moral Hazard and Soft Budget Constraints. Economic Research, No. 2, 17-27.

Lu, T., \& Dang, Y. (2014). Corporate Governance and Technological Innovation: A Comparison by Industry. Economic Research, No. 6, 115-128.

Mathers, A. M., Wang, B., \& Wang, X. S. (2016). Innovation and Price Informativeness. Financial Management, 8, 1-24.

Pang, J. R., Chen, D. P., \& Wang, W. (2019). Margin and Securities Lending System and Corporate Investment Behavior: Analysis Based on "External Governance" and "Information Learning" Channels. Investment Research, No. 4, 4-29.

Seiu, A. (2014). Firm Boundaries Matter: Evidence from Conglomerates and R\&D Activity. Journal of Financial Economics, 111,381-905. https://doi.org/10.1016/j.jfineco.2013.11.001

Su, D. W., \& Xiong, J. C. (2013). Stock Liquidity, Stock Price Information Content and CEO Compensation Contract. Economic Research, No. 11, 56-70.

Vuong, Q. (1989). Likelihood Ratio Tests for Model Selection and Non-Nested Hypothesis. Econometrica, 57, 307-334. https://doi.org/10.2307/1912557

Xiao, S., \& Zhao, S. (2012). Financial Development, Government Ownership of Banks and Firm Innovation. Journal of International Money and Finance, 31, 880-906. https://doi.org/10.1016/j.jimonfin.2012.01.006

$\mathrm{Xu}$, C. C., \& Yan, J. W. (2011). Research on the Principal-Agent Problem of State-Owned Enterprises. Economic Development, No. 1, 92-95.

Yang, J. W., Nie, S. J. (2010). Research on the Information Content of Stock Price and the Efficiency of Enterprise Capital Allocation. Management Science, No. 6, 81-90.

Yu, L. F., Tang, Y., \& Xu, J. G. (2014). Financing Constraints, Stock Price Information Content and Investment-Stock Price Sensitivity. Financial Research, No. 11, 159-174. 
Yuan, J. G., Hou, Q. S., \& Cheng, C. (2015). The Curse Effect of Corporate Political Resources: Based on the Investigation of Political Connections and Corporate Technological Innovation. Management World, No. 1, 139-155. 